\title{
Swelling pressure of compacted bentonite acting on constraining material with deformability
}

\author{
YASUTAKA WATANABE* and YUKIHISA TANAKA $†$
}

\begin{abstract}
In order to better understand the physical interactions between compacted bentonite and the host rock, the swelling pressure acting on a constraining material with slight deformability and the volume change of the compacted bentonite caused by unloading without consolidation history were investigated. A swelling test apparatus equipped with controls for applying a small strain and loading pressure was developed to mechanically simulate the elastic strain of a soft and a hard rock and large deformation of the constraining materials. After the equilibrium swelling pressure had been measured, the vertical pressure was unloaded. It was found that the slight deformation of the compacted bentonite decreased the swelling pressure. Furthermore, upon unloading, for the Na-bentonite with no consolidation history, after the equilibrium swelling pressure had been measured by a sufficiently confined condition, the slope angle of the unloading curve approximately equalled that of the normal consolidation line, although a slight non-linearity of the curve was observed in highly compacted bentonite. Based on the Mohr-Coulomb yield criterion, this indicated a mechanism whereby the shear strain in the saturation and one-dimensional swelling deformation processes effects an isotropy of swelling pressure and a nonlinearity of the unloading curve.
\end{abstract}

KEYWORDS: clays; expansive soils; laboratory tests

\section{INTRODUCTION}

The design of most geological disposal facilities for radioactive waste is based on the multibarrier concept, which involves natural host rocks and engineered barriers. Owing to their low permeabilities, compacted bentonite and bentonitebased materials can be used as engineered barriers to inhibit the migration of radioactive nuclides (Johansson et al., 2002; Chapman \& Hooper, 2012; NUMO, 2013; Sellin \& Olivier, 2013; Namioka et al., 2017). The swelling characteristics of compacted bentonite, which entails two aspects - namely, swelling pressure and deformation - play a crucial role in ensuring low permeability. With reference to Pusch (1992) and NUMO (2013), swelling deformation is important in terms of the self-sealing, which fills the primary space caused by construction difficulties, and the self-healing, which fills the gap generated by material erosion and creep deformation after saturation. The swelling pressure after swelling deformation is essential to ensure the physical stability of the facilities from a mechanical point of view.

In a comprehensive interpretation of expansive clays, the dry density or void ratio uniquely relates to the swelling pressure under the same material condition and solution (Komine \& Ogata, 2004; Karnland et al, 2007; Villar \& Lloret, 2008; Alonso et al., 2011; Gens et al., 2011; Lee et al., 2012; Wang et al., 2012; Navarro et al., 2017; Zeng et al., 2019; Jadda \& Bag, 2020). In terms of the self-sealing, it appears that there is a unique relationship between the swelling pressure and

Manuscript received 1 October 2020; revised manuscript accepted 19 May 2021. Published online ahead of print 24 September 2021. Discussion on this paper closes on 1 June 2023, for further details see p. ii.

Published with permission by the ICE under the CC-BY 4.0 license. (http://creativecommons.org/licenses/by/4.0/)

* Civil Engineering Research Laboratory, Central Research Institute of Electric Power Industry, Chiba, Japan

(Orcid:0000-0002-1858-3887).

$\uparrow$ Civil Engineering Research Laboratory, Central Research Institute of Electric Power Industry, Chiba, Japan. the final dry density of samples with a technological void (Zeng et al., 2020). To compare the swelling pressure among different bentonites, the effective montmorillonite dry density or the smectite partial density is used (JNC, 2000; Sato, 2008; Siddiqua et al., 2011) because the montmorillonite content of bentonite differs. The unique relationship is useful to estimate the swelling pressure if the final dry density of the compacted bentonite after swelling deformation can be determined. However, there is a variation in the measured swelling pressure, for various reasons, including the initial water content and the specimen height, if the conditions on the interlayer cation composition of montmorillonite and pore fluid chemistry are the same (Basma et al., 1995; Elsaidy et al., 2019; Tanaka \& Watanabe, 2019). It has also been established that the swelling pressure of FEBEX bentonite does not seem to be affected by the initial water content, although the swelling strain decreases with increasing initial water content (Villar \& Lloret, 2008). Focusing on a Na-bentonite, Kunigel-V1, produced in Japan, the measured swelling pressure varies considerably, even at the same dry density (Nakamura et al., 2010; Tanai et al., 2010). Through numerical simulations, Tanaka \& Watanabe (2019) found that the stiffness of the test cell affects the swelling pressure, and they also demonstrated the effects of several other factors on the swelling pressure test results. The stiffness of the surrounding materials might affect the swelling pressure. From the geotechnical point of view, the in situ confinement condition of the engineered barrier is also significant to analyse the stress evolution induced by saturation.

In Japan's disposal concepts, compacted bentonite is confined by host rocks, concrete materials, or backfill materials (NUMO, 2013; Namioka et al., 2017), which may manifest fractures, technological voids, or deformability. The pressures induced by the swelling of compacted bentonites have been measured using in situ tests (Nakayama et al., 2016; Zhao et al., 2016; Gracía-Siñeriz et al., 2019). However, it is difficult to understand the variations in the measured pressures in these tests based on the swelling pressure obtained from laboratory tests, even if both tests are performed at the same dry density. For an accurate evaluation of the swelling pressure acting on 
the constraining materials with deformability, it is important to understand in depth the effect of deformable constraining materials on the dry density-swelling pressure relationship.

Thus far, the swelling pressure and deformation have been discussed on the basis of the void ratio-effective stress relationship. Sridharan et al. (1986) measured the swelling pressures using three methods: free swell and load (swellconsolidation), swell under load (zero-swell) and no swell tests, which resulted in significantly different values. The swelling pressure obtained by the no swell method, which permitted a small deformation to maintain specimen volume, was lower than the values corresponding to the normal consolidation line obtained by the free swell and load test. Sridharan et al. (1986) suggested that the effect of the stress path in determining the swelling pressure was significant. Wang et al. (2012) investigated the stress path in detail. The swelling pressures measured by the pre-swell, zero-swell and constant-volume tests were compatible, and they were lower than the values in the swellconsolidation test. Cui et al. (2013) reported the unloadingreloading behaviours of undisturbed materials, which contained smectite, sampled at different depths. The unloading slope, which seemed to be bilinear, was observed, and thereafter, reloading showed a typical compression curve from the overconsolidated to the normal consolidated states. For this behaviour, Cui et al. (2013) propose a mechanism related to the swelling pressure; unloading below the swelling pressure is a process of collapsible microstructure creation, whereas reloading beyond the swelling pressure is a process of microstructure collapse. Furthermore, a hysteresis loop in the results of swell-consolidation tests and non-linearity of unloading curves have been reported (Chen et al., 2017; Guerra et al., 2019; Zhang et al., 2019), and the difference in the void ratio between the ordinal mechanical swelling line and non-linear curve has been interpreted as a result of osmotic swelling (Sahara et al., 2008; Kyokawa et al., 2020).

Considering the hysteresis loop mentioned above, the swelling pressure acting on the constraining materials at any dry density after swelling deformation depends on the stress path, as depicted in Fig. 1, making its estimation difficult by the unique relationship between the dry density and the swelling pressure. In practice, after the compacted bentonite was saturated under restrained conditions by host rocks, it is expected that the swelling deformation was induced by the decrease in the confining stress because of the erosion and creep deformation. Upon unloading without consolidation history after constant-volume saturation, the stress path becomes difficult to estimate.

Therefore, the swelling pressure of compacted bentonite acting on a constraining material with slight deformability -

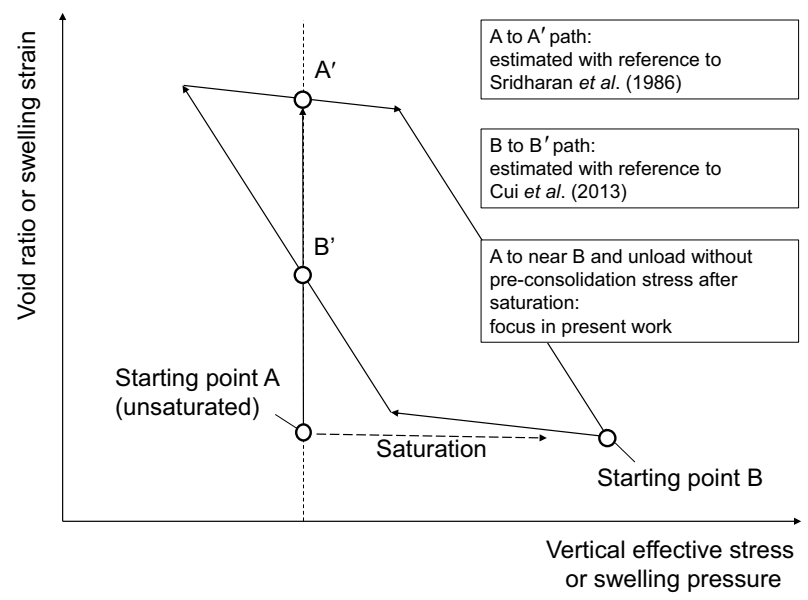

Fig. 1. Schematic image of stress paths after swelling deformation for example, the elastic strain in rocks - and the volume change from unloading without consolidation history were investigated. A swelling test apparatus equipped with controls for applying a small strain and loading pressure was developed to mechanically simulate the elastic strain and large deformation of constraining materials. The influence of the equilibrium swelling pressure under several confining conditions on the swelling deformation was examined. Furthermore, the relationship between the void ratio and mean effective stress in the swelling pressure and deformation tests, referred to as the one-dimensional consolidation test result, is discussed. A mechanism related to a non-linearity of the unloading curve was suggested.

\section{MATERIAL}

Na-bentonite (Kunigel-V1, Kunimine Industries Co., Ltd), mined from Yamagata Prefecture in Japan, was used. The physicochemical properties of the bentonite are listed in Table 1 . The leachable cations, which approximately correspond to the exchangeable cations, were identified after five rounds of leaching with a $1 \mathrm{~mol} / \mathrm{l}$ ammonium chloride $\left(\mathrm{NH}_{4} \mathrm{Cl}\right)$ solution. Leachable $\mathrm{Na}$ ions were dominant in the bentonite. The amount of methylene blue adsorbed was measured according to the Japanese industrial standard (JIS, 2019). Assuming that the methylene blue adsorbed on to the pure montmorillonite in the bentonite was $140 \mathrm{mmol} / 100 \mathrm{~g}$ (Watanabe \& Yokoyama, 2020), the montmorillonite content was estimated to be $51 \cdot 4 \%$. According to X-ray diffraction analysis, other than the montmorillonite, the bentonite contained quartz, feldspar, clinoptilolite, calcite, pyrite and dolomite.

\section{EXPERIMENTAL PROCEDURE \\ Test apparatus}

Figure 2 depicts the swelling pressure test apparatus equipped with controls for the application of a small strain and loading pressure. The apparatus comprises a stiff four-columned load frame with a stepping motor, strain wave gearing, stainless vessel and load cell. The specimen, compacted bentonite, was set in the test ring on the load cell. The lateral deformation of the test ring (made of stainless steel) caused by the swelling pressure is estimated as less than $5 \times 10^{-3} \%$ of the specimen radius. For example, the change in dry density would be less than $0.01 \mathrm{Mg} / \mathrm{m}^{3}$. The specimen was $20 \mathrm{~mm}$ high with $60 \mathrm{~mm}$ dia., including a vertical hole of $6.0 \mathrm{~mm}$ dia. at the centre. The piston connected to the motor was placed on the specimen. The small-scale deformation of the specimen was directly measured using a non-contact-type displacement gauge of $6.0 \mathrm{~mm}$ dia. and $19.3 \mathrm{~mm}$ long, as illustrated in Fig. 3. The gauge was inserted into the hole at the centre of the specimen, and the target plate was placed on the porous end piece at the bottom. The distance between the target and the top of the non-contact-type displacement

Table 1. Physicochemical properties of the bentonites used in this study

\begin{tabular}{|c|c|c|}
\hline & & Na-bentonite \\
\hline \multirow{3}{*}{\multicolumn{2}{|c|}{$\begin{array}{l}\text { Particle density of soil: } \mathrm{Mg} / \mathrm{m}^{3} \\
\text { Methylene blue adsorbed: } \mathrm{mmol} / 100 \mathrm{~g} \\
\text { Total of leachable cation: } \mathrm{meq} / 100 \mathrm{~g}\end{array}$}} & $2 \cdot 674$ \\
\hline & & 72 \\
\hline & & $106 \cdot 7$ \\
\hline \multirow{4}{*}{ Amount of leachable cation: $\mathrm{meq} / 100 \mathrm{~g}$} & $\mathrm{Na}$ & $57 \cdot 9$ \\
\hline & $\mathrm{K}$ & 1.9 \\
\hline & $\mathrm{Ca}$ & $44 \cdot 1$ \\
\hline & $\mathrm{Mg}$ & $2 \cdot 8$ \\
\hline
\end{tabular}




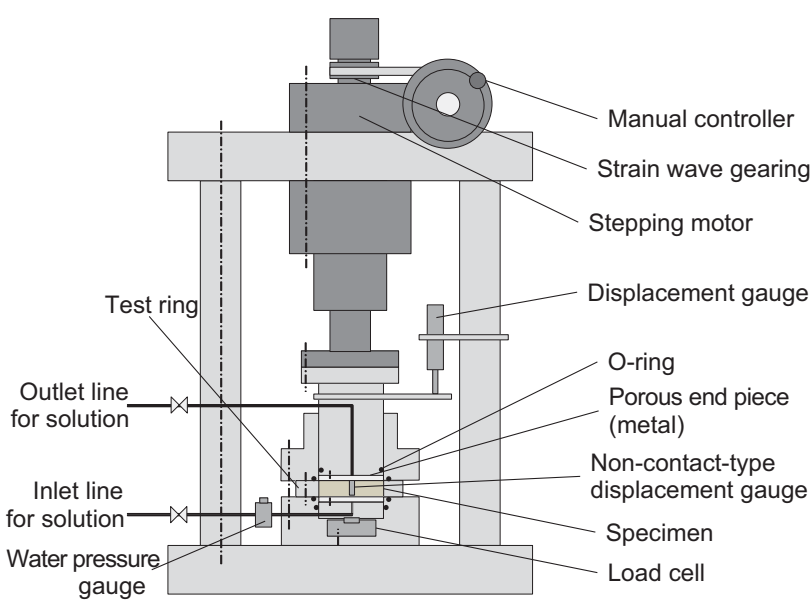

Fig. 2. Swelling pressure test apparatus equipped with small strain and loading pressure controls

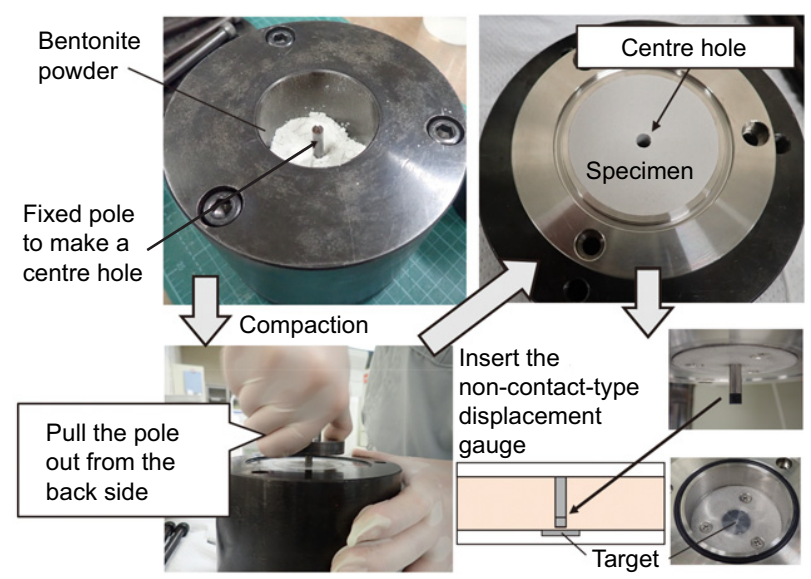

Fig. 3. Setting of non-contact-type displacement gauge

gauge, which is mainly used to control the small strain of the specimen during the hydration to measure the equilibrium swelling pressure under various conditions of slight deformability of restraining materials, was measured with a precision of $0 \cdot 1 \mu \mathrm{m}$. This equipment can provide a precise displacement of the specimen, cancelling the extra deformation of the test apparatus due to swelling pressure. In addition, the final dry density of the specimen can be calculated using the value measured by the non-contact-type displacement gauge. The displacement gauge for the large-scale deformation of the specimen, which was mainly used in the swelling deformation test, was located between the piston and frame. The solution was supplied from the bottom of the specimen. An outlet line for the solution was connected to the upper side of the specimen. The vertical pressure and displacements were recorded using a computer, and the displacement or vertical pressure could be automatically controlled for the purpose of the experiments, as described below.

\section{Production of specimen}

The compacted bentonite was produced by static compaction. As shown in Fig. 3, the powder bentonite was compacted in the mould, which was equipped with a $6.0 \mathrm{~mm}$ dia. pole to secure the space for a hole inside. After the compaction, the pole was pulled out, and the space required to insert the non-contact-type displacement gauge remained. The compacted bentonite with $6.0 \mathrm{~mm}$ centre hole was transferred into the test ring. The height of the specimen was measured by caliper. The initial dry density before the water was supplied was calculated using the volume of the specimen, considering the hole inside.

\section{Swelling pressure test with small strain control}

To simulate the elastic deformation of the constraining material caused by the swelling pressure of the compacted bentonite, the height of the specimen was continuously adjusted according to the changes in the swelling pressure during the hydration of specimen. The top porous end piece was set in contact with the specimen at the beginning of the test. After the water was supplied, the increment in the swelling pressure was measured by the load cell. The elastic deformation caused in the constraining material was calculated using Hooke's law, as defined in equation (1). The height of the specimen was mechanically controlled by the stepping motor, after the assumed elastic modulus $(E)$ of the constraining material was set.

$$
\Delta H=\left(\Delta P_{\mathrm{s}} / E\right) H_{0}
$$

where $\Delta H(\mathrm{~m})$ denotes the compressive elastic displacement of the constraining material caused by the incremental swelling pressure $\Delta P_{\mathrm{s}}(\mathrm{MPa}) . H_{0}(\mathrm{~m})$ is the initial height of the specimen and $E(\mathrm{MPa})$ represents the assumed elastic modulus of the constraining material. The small strain of the specimen was achieved by moving the piston placed on the specimen automatically with a time step of $1 \mathrm{~s}$. The displacement, $\Delta H$, given in the axial direction during the time step was calculated by equation (1). Through repetition of this operation, the vertical pressure gradually became constant with elapsed time; thus, the equilibrium swelling pressure was obtained. In this study, it is assumed that the physical interaction between the compacted bentonite and the constraining material with slight deformability occurs under the same thickness condition.

The $E$ used in equation (1) is physically equal to the equivalent axial stiffness of the test cell, $K_{\text {sys,a }}(\mathrm{MPa})$, as defined in equation (2) (Tanaka \& Watanabe, 2019).

$$
K_{\text {sys }, \mathrm{a}}=H / D_{\mathrm{a}}
$$

where $D_{\mathrm{a}}(\mathrm{m} / \mathrm{MPa})$ is the axial deformation of the test cell per unit swelling pressure and $H(\mathrm{~m})$ is the height of the specimen. The value of $K_{\text {sys,a }}$ for the apparatus used in previous studies varied from $4.94 \times 10^{1}$ to $3.70 \times 10^{4} \mathrm{MPa}$, and the equilibrium swelling pressure was dependent on $K_{\text {sys,a }}$ (Tanaka \& Watanabe, 2019). To compare the test results, the normalised swelling pressure was used by dividing the swelling pressure at $E=750-3500 \mathrm{MPa}$ into that at $37000 \mathrm{MPa}$, assuming the latter was the most constrained condition by the rocks.

\section{Swelling deformation test}

To study the swelling deformation after it reached the equilibrium swelling pressure, the change in the specimen height upon unloading was measured. The small strain control was turned off, and a vertical pressure equal to the equilibrium swelling pressure was applied to the specimen. The height of the specimen was maintained by balancing the vertical and swelling pressures. Subsequently, the vertical pressure was unloaded, and the swelling deformation was measured using a displacement gauge connected to the piston. The vertical pressure was reduced in steps, and the swelling deformation was measured when it approximately converged to a constant value at each stage. The swelling deformation ratio, given by equation (3), is defined as the 
Table 2. Experimental programme of the swelling pressure test and swelling deformation test

\begin{tabular}{l|c|c|c|c}
\hline Bentonite & $\begin{array}{c}\text { Approximate initial dry density for } \\
\text { simple notation: } \mathrm{Mg} / \mathrm{m}^{3} *\end{array}$ & $\begin{array}{c}\text { Initial dry } \\
\text { density: } \mathrm{Mg} / \mathrm{m}^{3}\end{array}$ & $\begin{array}{c}\text { Assumed elastic } \\
\text { modulus: } \mathrm{MPa}\end{array}$ & $\begin{array}{c}\text { Dry density at equilibrium } \\
\text { swelling pressure: } \mathrm{Mg} / \mathrm{m}^{3}\end{array}$ \\
\hline Na-bentonite & 1.8 & 1.805 & 37000 & 1.804 \\
& 1.6 & 1.797 & 3500 & 1.794 \\
& & 1.575 & 37000 & 375 \\
& \multirow{2}{*}{1.4} & 1.578 & 7500 & 1.594 \\
& & 1.412 & 37000 & 1.574 \\
& & 1.386 & 3500 & 1.412 \\
\hline
\end{tabular}

*Approximated initial dry density is used as a simple notation in the main text and figure legends hereinafter.

ratio of the incremental height of the specimen to the initial height of the specimen.

$$
\varepsilon_{\mathrm{sw}}=\left(H-H_{0}\right) / H_{0} \times 100
$$

where $\varepsilon_{\mathrm{sw}}(\%)$ is the swelling deformation ratio. The void ratio after swelling deformation was calculated using the volume of the swollen specimen, considering the space under the non-contact-type displacement gauge. After the swelling deformation had occurred, the water content was measured using the Japanese industrial standard (JIS A 1203; JIS, 2009), and the degree of saturation was calculated.

\section{Experimental programme}

The experimental programme of the swelling pressure tests with small strain control and swelling deformation tests is listed in Table 2. The $E$ of the constraining material was set in the range of 750-37 $000 \mathrm{MPa}$, simulating both soft and hard rocks. Compacted bentonite, with a water content of $10 \%$, was produced; its initial dry density was in the range of $1 \cdot 4-1 \cdot 8 \mathrm{Mg} / \mathrm{m}^{3}$. The dry densities at the equilibrium swelling pressure, namely, the final dry densities, are also listed in Table 2. Deionised water (hereinafter referred to as 'water') was used for saturating the specimens. The dry density when the equilibrium swelling pressure was calculated using the displacement of the specimen was measured using the non-contact-type displacement gauge, considering the slight space between the gauge and the target. The swelling deformation test using a dry density of $1.6 \mathrm{Mg} / \mathrm{m}^{3}$ at $E=750 \mathrm{MPa}$ could not be executed, because the piston was stuck in the apparatus during unloading.

\section{RESULTS AND DISCUSSION}

Equilibrium swelling pressure dependent on slight deformability

For compacted bentonite at a dry density of $1.6 \mathrm{Mg} / \mathrm{m}^{3}$, the relation between the measured displacement of the specimen and elapsed time is depicted in Fig. 4. The displacement of the specimen was only $0.001 \mathrm{~mm}$ at $E=37000 \mathrm{MPa}$ during the swelling pressure test. At $E=3500 \mathrm{MPa}$ and $750 \mathrm{MPa}$, the displacements of the specimen were approximately $0.01 \mathrm{~mm}$ and $0.04 \mathrm{~mm}$, respectively. Each displacement corresponded to a volumetric strain of $0.006 \%, 0.053 \%$ and $0.204 \%$, compared with the initial value of the specimen. The $0 \cdot 204 \%$ volumetric strain reduced the calculated dry density from 1.578 to $1.574 \mathrm{Mg} / \mathrm{m}^{3}$. A larger deformability of the material confining the specimen resulted in a larger deformation of the specimen after the water was supplied.

The relationship between the vertical pressure and elapsed time is shown in Fig. 5. Immediately after the water was supplied, the vertical pressure increased and reached its first peak. The drop in swelling pressure was observed in

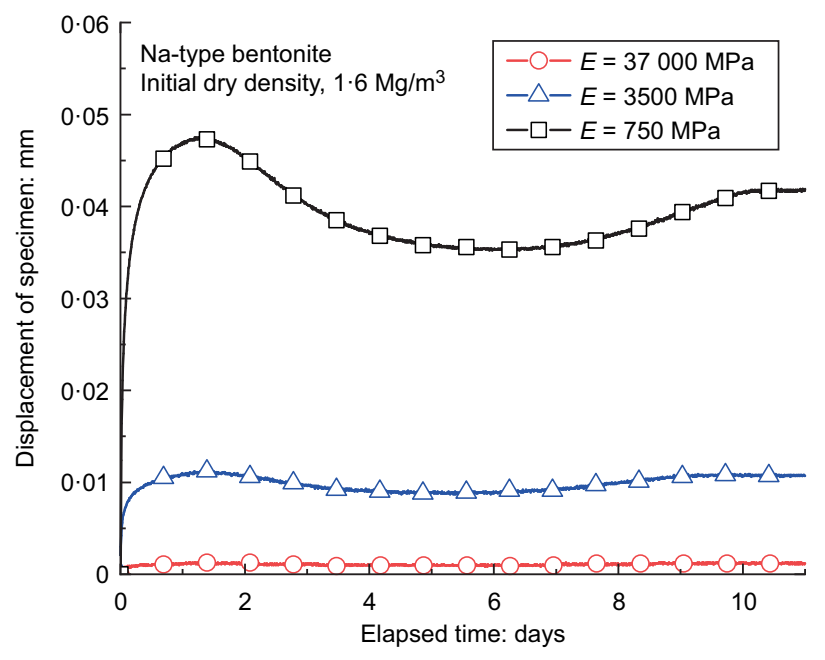

Fig. 4. Relationship between displacement of specimen and elapsed time $\left(1.6 \mathrm{Mg} / \mathrm{m}^{3}\right.$ of initial dry density)

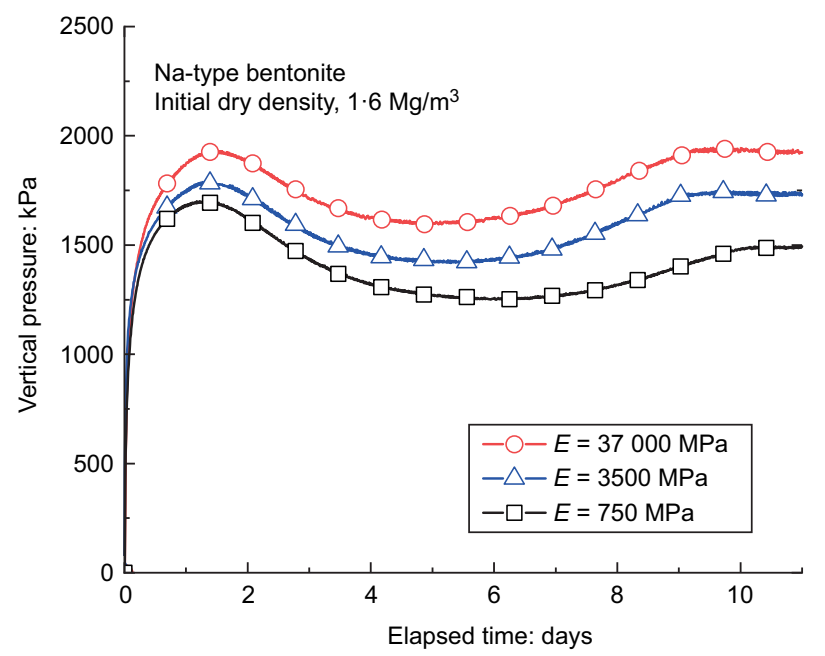

Fig. 5. Relationship between vertical pressure and elapsed time (1.6 $\mathrm{Mg} / \mathrm{m}^{3}$ of initial dry density)

the compacted bentonite. This was presumably caused by the rearrangement of the montmorillonite stacks and the increased interlamellar spacing during infiltration (Tanaka \& Watanabe, 2019). Thereafter, it increased again to a constant value. At $E=37000 \mathrm{MPa}$, the vertical pressure was the highest, and the equilibrium swelling pressure was $1950 \mathrm{kPa}$. At the smallest elastic modulus, $E=750 \mathrm{MPa}$, the equilibrium swelling pressure was approximately $1480 \mathrm{kPa}$. The equilibrium swelling pressure decreased by $24 \%$ because of 
different specimen confinement conditions, even though the dry density remained almost unchanged. Furthermore, although the slight lateral deformation of the test ring would contribute to dry density variation, this is not sufficient to explain the higher swelling pressure observed under the more confined condition in the vertical direction. It can be concluded that the larger deformation of the specimen decreased the swelling pressure.

Figure 6 depicts the relationship between the equilibrium swelling pressure and the dry density of the specimen across all experimental cases. At a dry density of $1.8 \mathrm{Mg} / \mathrm{m}^{3}$, a $21 \%$ reduction in the equilibrium swelling pressure from 10650 to $8390 \mathrm{kPa}$ was observed at different specimen confinement conditions from $E=37000$ to $3500 \mathrm{MPa}$. At a $1.4 \mathrm{Mg} / \mathrm{m}^{3}$ dry density, a $16 \%$ reduction in the equilibrium swelling pressure from 580 to $490 \mathrm{kPa}$ was observed under the different specimen confinement conditions, from $E=37000$ to $750 \mathrm{MPa}$. However, it included a reduction in the final dry density. To compare these results, the relationship between the swelling pressure, normalised by the equilibrium swelling pressure at $E=37000 \mathrm{MPa}$, and the deformation ratio of the specimen, calculated using equation (3), is shown in Fig. 7. In the most confined condition for the specimens, for

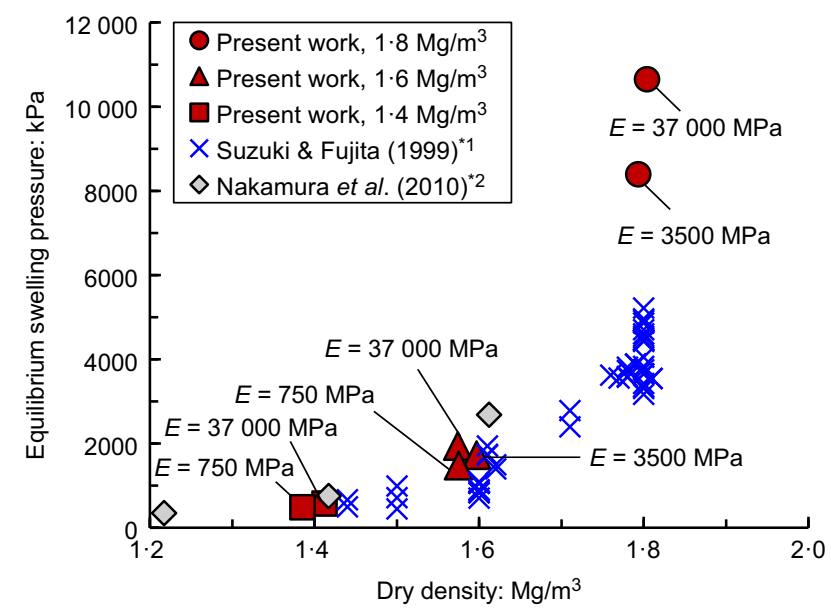

Fig. 6. Relationship between the equilibrium swelling pressure and dry density corrected by the displacement of the specimen (note: $* 1$, external load-type apparatus, axial stiffness of test cell is low; $*^{2}$, built-in load cell-type apparatus, axial stiffness of test cell is high)

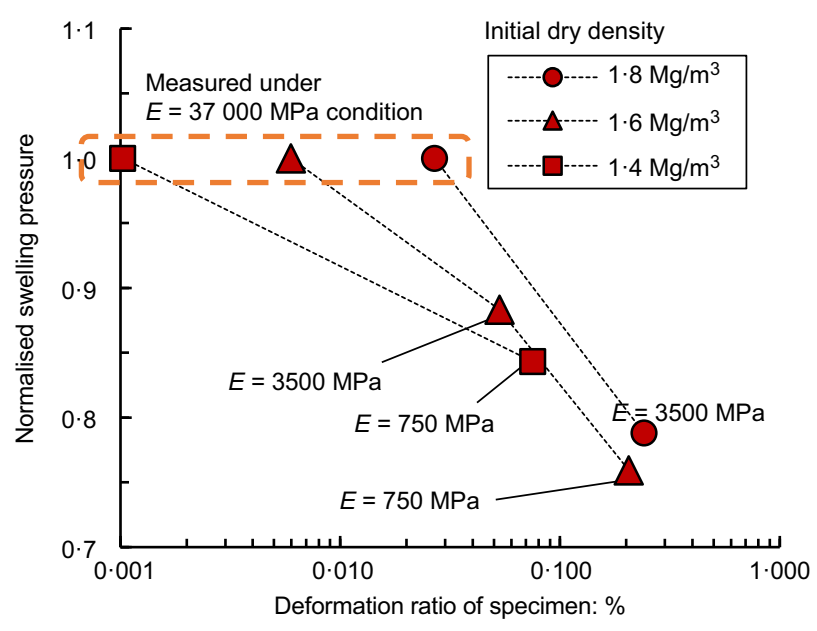

Fig. 7. Relationship between normalised swelling pressure and deformation ratio of specimen: the swelling pressure was normalised to that measured under the most confined condition $(E=37000 \mathrm{MPa})$
$E=37000 \mathrm{MPa}$, the deformation ratio increased along with the dry density as the swelling pressure increased. The equilibrium swelling pressure decreased to $75-80 \%$ at approximately $0.2 \%$ of the deformation ratio.

In Fig. 6, comparing the results with data obtained in previous studies using Na-bentonite (Kunigel-V1) with an approximately $10-11 \%$ water content, the equilibrium swelling pressure at $E=37000 \mathrm{MPa}$ was approximately equal to that measured by Nakamura et al. (2010). Their results were a consequence of the test cell having a higher axial stiffness. This indicates that there was almost no influence of the inserted non-contact-type displacement gauge on the swelling pressure measurement. At a dry density of $1.8 \mathrm{Mg} / \mathrm{m}^{3}$, there was a significant difference in the equilibrium swelling pressure between the present study and that conducted by Suzuki \& Fujita (1999). Their results might have been obtained by using a test cell with a lower axial stiffness. Although a small increase in dry density may lead to a large increase in swelling pressure, the pressure difference at $1.8 \mathrm{Mg} / \mathrm{m}^{3}$ cannot be the result of a single influence. Tanaka \& Watanabe (2019) theoretically clarified that the axial stiffness of the experimental apparatus influenced the swelling pressure. The influence of the slight deformability of the specimen on the swelling pressure increased at higher dry densities.

As in the laboratory testing, the slight deformability of the compacted bentonite, which depends on the site-specific confinement condition of the constraining material, changes the swelling pressure evolution. This is specifically observed at higher dry densities, even if there is almost no change in the value of the dry density during saturation. In this study, the water content immediately after the swelling pressure reached equilibrium could not be measured. A further study should attempt to investigate the effect of $E$ in terms of the hydration state at the equilibrium swelling pressure, although the specimen had been saturated after the swelling deformation test.

Swelling deformation with unloading confining pressure

For the compacted bentonite at a $1 \cdot 6-\mathrm{Mg} / \mathrm{m}^{3}$ dry density, time series data for the vertical pressure and swelling deformation ratio are depicted in Fig. 8. The specimen was

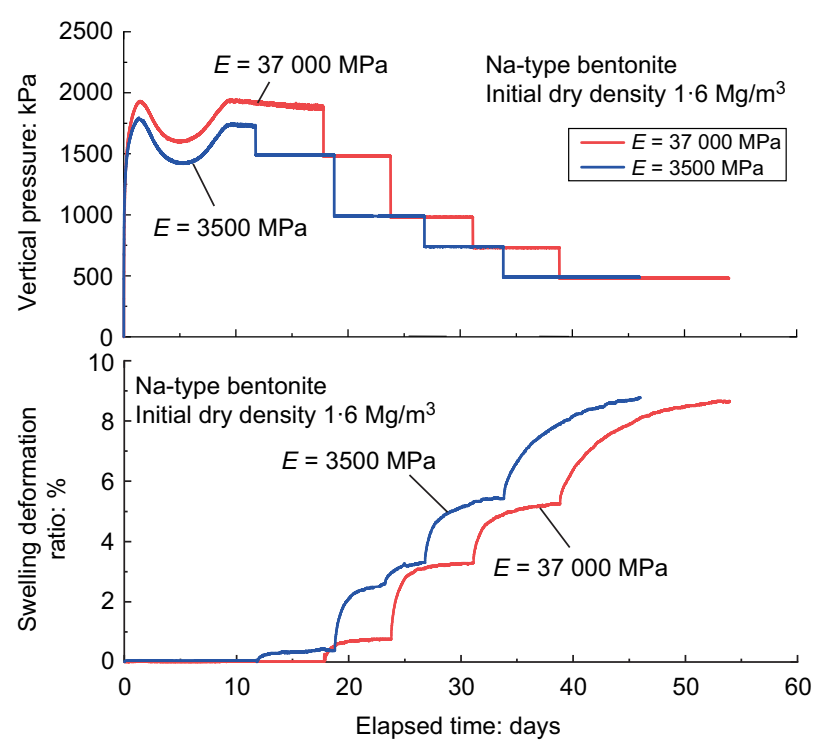

Fig. 8. Time series data for the vertical pressure and swelling deformation ratio $\left(1.6 \mathrm{Mg} / \mathrm{m}^{3}\right.$ of initial dry density) 
confirmed to be fully saturated because the degree of saturation ranged from $99 \cdot 2 \%$ to $107 \cdot 3 \%$ at the end of the experiment.

In the unloading process, after the equilibrium swelling pressure had been measured, the swelling deformation ratio increased and gradually converged for each confining condition. A smaller vertical pressure resulted in a larger swelling deformation ratio of the compacted bentonite. Although the equilibrium swelling pressure changed, depending on the slight deformability of the specimen in the swelling pressure test, there was almost no change in the swelling deformation ratio after unloading, despite varying the $E$ between $37000 \mathrm{MPa}$ and $3500 \mathrm{MPa}$.

The relationship between the vertical pressure and swelling deformation ratio across all experiments is depicted in Fig. 9. As mentioned earlier, there was a difference in the deformation ratio at each vertical pressure, especially when the deformation ratio was considerably small (Fig. 7). However, the difference in the swelling deformation ratio was significantly reduced after unloading, in the range whereby the swelling deformation ratio was greater than $0 \cdot 2 \%$. This suggested that the influence of deformability on the swelling pressure was limited to approximately $0 \cdot 2 \%$ of the strain range. In other words, the equilibrium swelling pressure

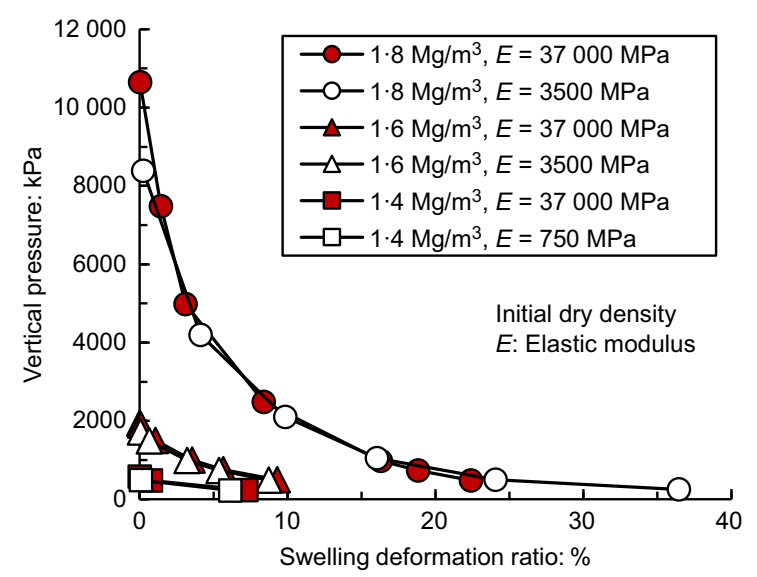

Fig. 9. Relationship between vertical pressure and swelling deformation ratio induced at initial hydration had no effect on the swelling deformation in the larger strain range.

Regarding the relationship between swelling and physical deformation, Sridharan et al. (1986) schematically and experimentally explained the increase in the swelling pressure toward the normal consolidation line (NCL) based on the fixed volume of the specimen during saturation. Therefore, the series behaviour from the equilibrium swelling pressure to swelling deformation was compared with the results of the consolidation tests. The relationship between the void ratio of the specimen and the vertical pressure is shown in Fig. 10. The consolidation test results of the compacted bentonite, Kunigel-V1, at dry densities of $1.6 \mathrm{Mg} / \mathrm{m}^{3}$ and $1.8 \mathrm{Mg} / \mathrm{m}^{3}$, as reported by Namikawa \& Kanno (1997), are also illustrated in Fig. 10. They reported that the compression indices were 0.27 and 0.21 for Kunigel-V1 at dry densities of $1.6 \mathrm{Mg} / \mathrm{m}^{3}$ and $1.8 \mathrm{Mg} / \mathrm{m}^{3}$, respectively. At a dry density of $1.4 \mathrm{Mg} / \mathrm{m}^{3}$, the equilibrium swelling pressure was remarkably plotted beyond the NCL. Furthermore, Sasakura et al. (2002) performed a swell-consolidation test using Kunigel-V1, which initially swelled by $19 \%$ in swelling rate (pre-swell, $19 \%$ ) during saturation and was consolidated. The dry density of the compacted bentonite changed from $1.62 \mathrm{Mg} / \mathrm{m}^{3}$ to $1.36 \mathrm{Mg} / \mathrm{m}^{3}$ upon the completion of swelling. The slopes with the compression indices of the specimen taken pre-swell $0 \%$ and $19 \%$ are shown in Fig. 10.

Before unloading, the equilibrium swelling pressure (allowing points) was close to the NCL obtained by Sasakura et al. (2002), although the stresses were above the consolidation test results. As the unloading progressed, the stress point moved along the NCL with linearity, especially in the case of $E=37000 \mathrm{MPa}$ for $1.6 \mathrm{Mg} / \mathrm{m}^{3}$. For the dry density of $1.8 \mathrm{Mg} / \mathrm{m}^{3}$, the stress point moved along that line with a small non-linearity at the beginning of unloading. Notably, the compression curves for specimens with different initial dry densities, which are saturated under different vertical stresses at the same initial dry density, are different in the range of low consolidation pressure, and gradually converge in the range of higher pressures (Zhang et al., 2016). Although the compression index of bentonite depends on the initial void ratio, the stress point moved approximately parallel to the NCL of the swollen specimen.

Therefore, for the specimen with no consolidation history after the equilibrium swelling pressure was measured by a

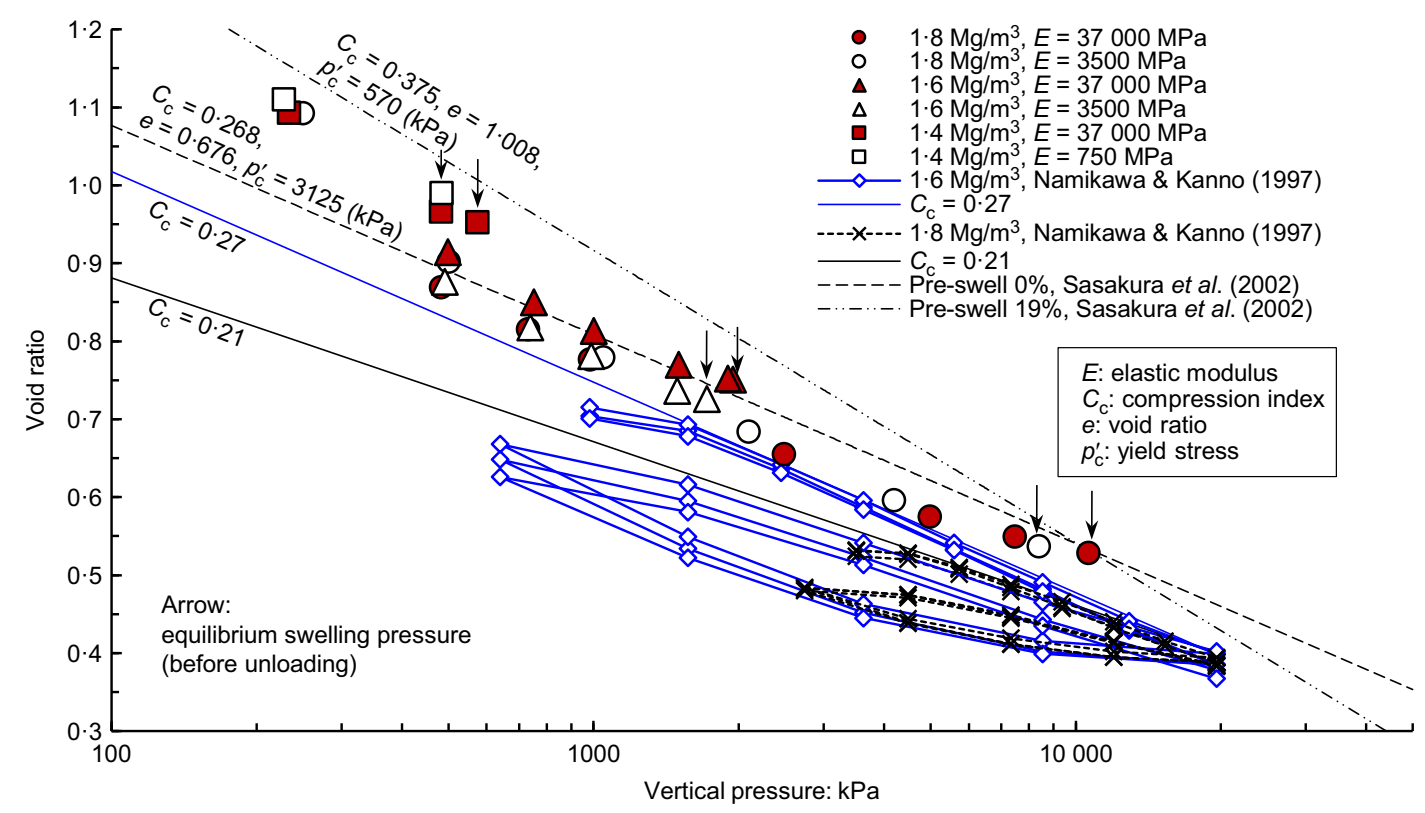

Fig. 10. Relationship between specimen void ratio and vertical pressure (Kunigel-V1) 
sufficiently confined condition, the slope angle of the unloading curve was approximately equal to that of the NCL. However, a slight non-linearity of the unloading curve was observed in highly compacted bentonite. Almost no elastic expansion of the specimen was observed during unloading, suggesting that the stress history by compaction was almost lost during saturation.

\section{Effect of shear stress in one-dimensional swelling deformation} on swelling pressure

Tanaka \& Watanabe (2016) simulated the one-dimensional unloading behaviour of the compacted Kunigel-V1 in a normally consolidated state, using the modified Cam Clay model (Roscoe \& Burland, 1968). According to that simulation, the yield surface was reached as the unloading progressed and plastic strain occurred, although the specimen was elastic at the beginning of the unloading. With further unloading, $\sigma_{\mathrm{r}}^{\prime}$ and $\sigma_{\mathrm{a}}^{\prime}$ satisfied the Mohr-Coulomb yield criterion, as defined in equation (4), before the stress ratio of the deviator stress to the effective stress, $q / p^{\prime}$, reached the critical state parameter, $M$.

$$
\sigma_{\mathrm{r}}^{\prime} / \sigma_{\mathrm{a}}^{\prime}=\left(1+\sin \phi^{\prime}\right) /\left(1-\sin \phi^{\prime}\right)
$$

where $\sigma_{\mathrm{r}}^{\prime}$ and $\sigma_{\mathrm{a}}^{\prime}$ are the effective stresses $(\mathrm{kPa})$ in the radial and axial directions, respectively, and $\phi^{\prime}$ is the internal friction angle (degrees). In the triaxial extension test using a wet clay, Roscoe \& Burland (1968) reported that $\sigma_{\mathrm{r}}^{\prime}$ and $\sigma_{\mathrm{a}}^{\prime}$ satisfied equation (4) before $q / p^{\prime}$ reached $M$. They also reported that $q / p^{\prime}$ at rupture in the extension tests could be predicted from the observed value of $q / p^{\prime}$ at rupture in compression tests by the Mohr-Coulomb yield criterion. Therefore, in the present study it is assumed that the stresses upon unloading, except for the initial slope just after unloading, can be expressed by equation (4).

As shown in Fig. 11, the deviator stress of compacted Kunigel-V1 reaches its maximum and becomes constant beyond an axial strain of approximately $4 \%$. The internal friction angle was $16.5^{\circ}$ in the undrained-consolidation triaxial test (Namikawa et al., 2004). This axial strain, which can be considered a critical state, corresponds to $6 \%$ of the shear strain. It is assumed that the effective stress is $\sigma_{\mathrm{r}}^{\prime}>\sigma_{\mathrm{a}}^{\prime}$ at a swelling deformation of more than approximately $6 \%$. Thus, the mean effective stress $\left(=\left(\sigma_{\mathrm{r}}^{\prime}+2 \sigma_{\mathrm{a}}^{\prime}\right) / 3\right)$ was calculated using the measured $\sigma_{\mathrm{a}}^{\prime}$ and calculated $\sigma_{\mathrm{r}}^{\prime}$ for the data in the range of more than $6 \%$ of the swelling deformation rate. The relationship between the void ratio and the mean effective stress is shown in Fig. 12. The equilibrium

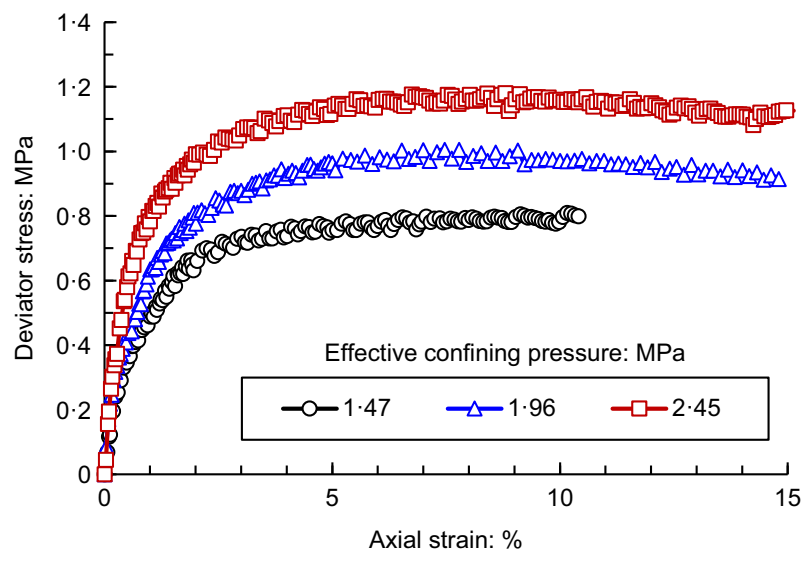

Fig. 11. Relationship between deviator stress and axial strain in undrained triaxial test for Kunigel-V1 at dry density of $1.6 \mathrm{Mg} / \mathrm{m}^{3}$ (Namikawa et al., 2004)

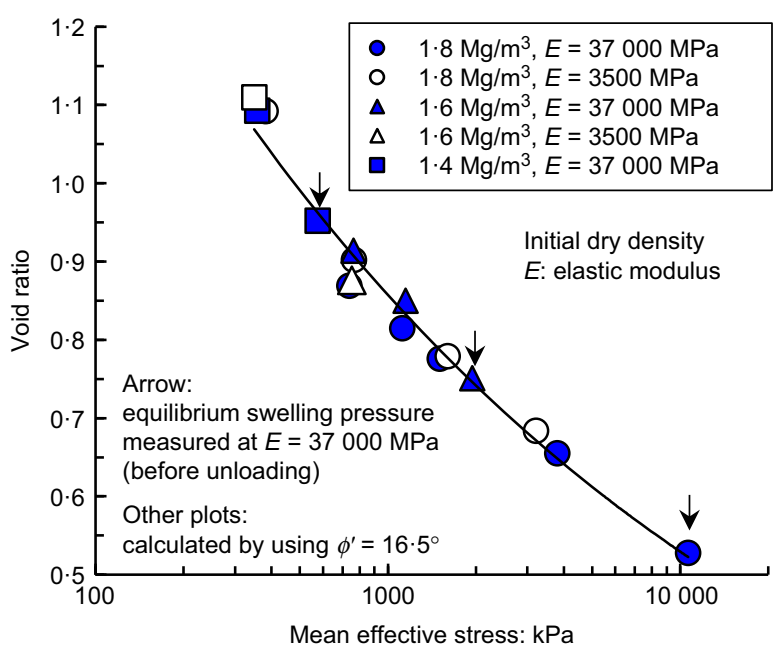

Fig. 12. Relationship between void ratio and mean effective stress. The mean effective stress was calculated using the measured vertical pressure and the internal friction angle, $\phi^{\prime}, 16 \cdot 5^{\circ}$

swelling pressure measured at $E=37000 \mathrm{MPa}$ was plotted as the mean effective stress. This is compatible with the swelling pressure of compacted Kunigel-V1 measured under a sufficiently confined condition being almost isotropic at a dry density of $1.6 \mathrm{Mg} / \mathrm{m}^{3}$ (Kudo et al., 2005). To confirm the isotropic state, this study observed the microstructure of the specimen by scanning electron microscope (SEM), as shown in Fig. 13. Many aggregates of montmorillonite distributed in both the cross-section perpendicular to the direction of compaction, and the cross-section along the direction of compaction. Because there was no obvious orientation of clay particles before saturation, this suggested that isotropic swelling could have occurred. Using SEM photography, Sato \& Suzuki (2003) also observed no orientation of clay particles for compacted Kunigel-V1. Furthermore, they observed that layers of clay particles were oriented perpendicularly to the compaction in the compacted montmorillonite, which indicated that the smectite content affected the orientation properties of the clay particles. This is because there was almost no microstructure anisotropy for compacted Kunigel-V1, which contained approximately $50 \mathrm{wt} \%$ of accessory minerals having larger particle sizes.

The calculated mean effective stress in the unloading process agreed with the relationship between the equilibrium swelling pressures measured at $E=37000 \mathrm{MPa}$ and void ratio. This indicates that if the shear strain is allowable owing to the deformation of the specimen, the swelling pressure is non-isotropic, and the measured equilibrium swelling pressure becomes less than the mean effective stress. It appears that the equilibrium swelling pressure measured by the insufficient confining condition (e.g. $0 \cdot 2 \%$ deformation ratio at $E=3500 \mathrm{MPa}$ in $1.8 \mathrm{Mg} / \mathrm{m}^{3}$ ) is not equal to the mean effective stress because of a slight shear strain during saturation. As indicated by Cui et al. (2013), the microstructure probably changes when a large volume of onedimensional swelling deformation, such as a kneading effect, is applied. Upon unloading, the slight shear strain may facilitate the microstructure change of the compacted bentonite; however, the shear effect on the microstructure requires further study.

Therefore, the swelling deformation of compacted bentonite saturated under a sufficiently confining condition with no consolidation history represents an approximately linear effective stress path similar to that of the NCL. This indicated a mechanism whereby the shear strain in the saturation and one-dimensional swelling deformation 

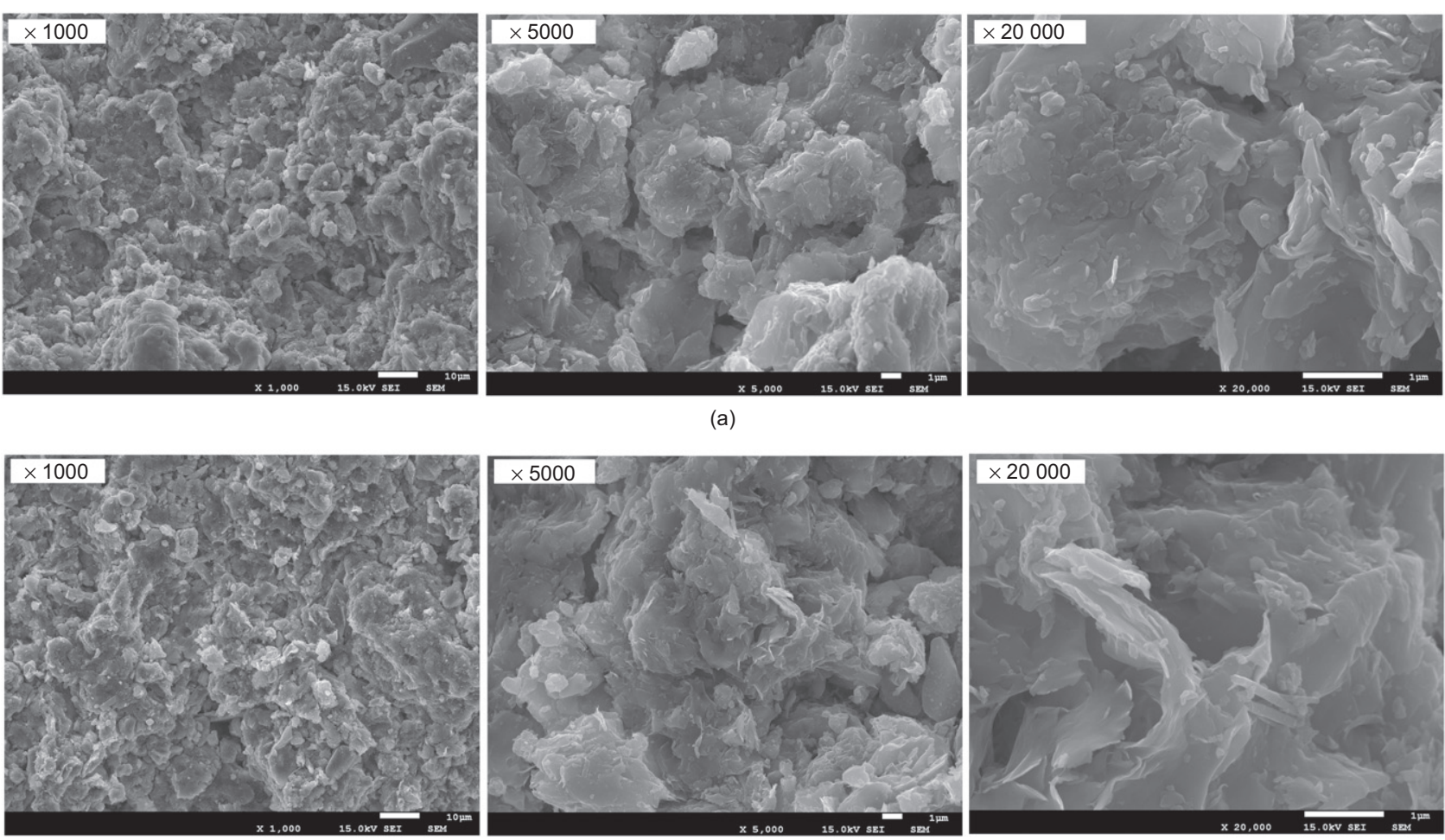

(a)
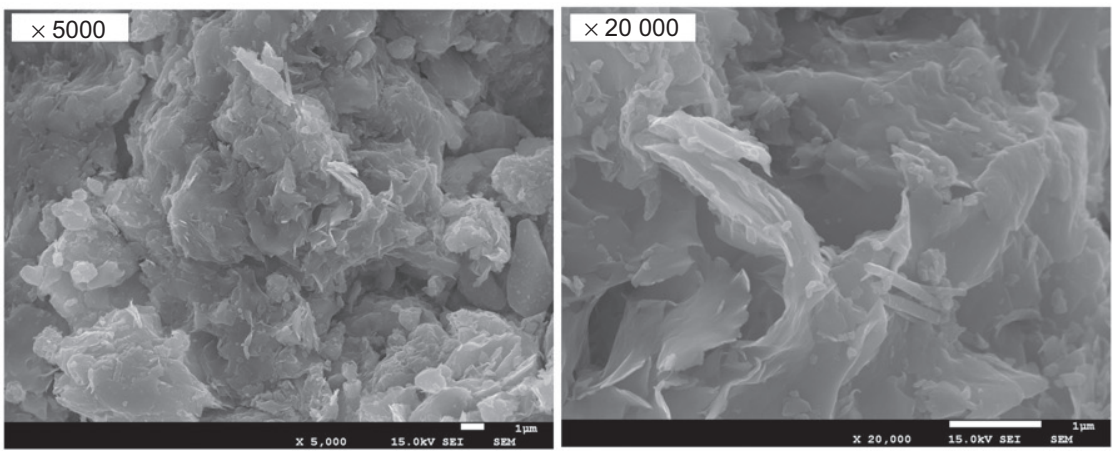

(b)

Fig. 13. SEM micrographs of compacted bentonite (Kunigel-V1) with a dry density of $1 \cdot 6 \mathrm{Mg} / \mathrm{m}^{3}$ : (a) cross-section perpendicular to the direction of compaction; (b) cross-section along the direction of compaction

processes effect an isotropically swelling pressure and a non-linearity of the unloading curve. Moreover, the approximated equilibrium swelling pressure in each confining stress could be estimated through the swelling deformation test after the swelling pressure had been measured under a restrained condition.

\section{CONCLUSIONS}

The swelling pressure evolution of compacted Na-bentonite acting on a constraining material with slight deformability (e.g. the elastic strain of rocks) was investigated, as well as the subsequent swelling deformation during unloading. First, it was found that the slight deformation of compacted bentonite, the engineered barrier, decreased the swelling pressure. In the small strain range between 0.001 and $0.2 \%$, the displacement of the specimen decreases the swelling pressure, thereby leading to a precise estimation of the swelling pressure that occurs in the repository under a bentonite-rock interaction. A more precise estimation of the swelling pressure is also useful for evaluating the physical steady state.

Second, for the compacted Na-bentonite that had no consolidation history, it was found that the stress path at unloading approximately adheres to the NCL, although a slight non-linearity of the unloading curve was observed in highly compacted bentonite. Notably, based on the MohrCoulomb yield criterion, the calculated mean effective stress in the unloading process agreed with the relationship between the equilibrium swelling pressures measured under a sufficient confining condition $(E=37000 \mathrm{MPa})$ and the void ratio. This indicated a mechanism whereby the shear strain in the saturation and one-dimensional swelling deformation processes effects an isotropically swelling pressure and a non-linearity of the unloading curve. This understanding leads to support an accurate evaluation of the bentonite-rock interaction, including the swelling characteristics.

\section{NOTATION}

$C_{\mathrm{c}}$ compression index

$D_{\text {a }}$ axial deformation of the test cell per unit swelling pressure

$E$ assumed elastic modulus of the constraining material

$e$ void ratio

$H$ height of the specimen

$H_{0} \quad$ initial height of the specimen

$K_{\text {sys,a }}$ equivalent axial stiffness of the test cell

$p^{\prime}$ effective stress

$p_{\mathrm{c}}^{\prime} \quad$ yield stress

$q$ deviator stress

$\Delta H \quad$ compressive elastic displacement of the constraining material

$\Delta P_{\mathrm{s}} \quad$ incremental swelling pressure

$\varepsilon_{\mathrm{sw}} \quad$ swelling deformation ratio

$\sigma_{\mathrm{a}}^{\prime}$ effective stress in the axial direction

$\sigma_{\mathrm{r}}^{\prime}$ effective stress in the radial direction

$\phi^{\prime}$ internal friction angle

\section{REFERENCES}

Alonso, E. E., Romero, E. \& Hoffmann, C. (2011). Hydromechanical behaviour of compacted granular expansive mixtures: experimental and constitutive study. Géotechnique 61, No. 4, 329-344, https://doi.org/10.1680/geot.2011.61.4.329.

Basma, A. A., Al-Homoud, A. S. \& Husein, A. (1995). Laboratory assessment of swelling pressure of expansive soils. Appl. Clay Sci. 9, No. 5, 355-368.

Chapman, N. \& Hooper, A. (2012). The disposal of radioactive wastes underground. Proc. Geol. Assoc. 123, No. 1, 46-63.

Chen, Z. G., Tang, C. S., Zhu, C., Shi, B. \& Liu, Y. M. (2017). Compression, swelling and rebound behavior of GMZ bentonite/additive mixture under coupled hydro-mechanical condition. Engng Geol. 221, 50-60.

Cui, Y. J., Nguyen, X. P., Tang, A. M. \& Li, X. L. (2013). An insight into the unloading/reloading loops on the compression curve of natural stiff clays. Appl. Clay Sci. 83-84, 343-348.

Elsaidy, H., Yan, W. M. \& Pender, M. J. (2019). A novel formula for the prediction of swelling pressure of compacted expansive soils. 
Géotechnique Lett. 9, No. 3, 231-237, https://doi.org/10. 1680/jgele.18.00203.

Gens, A., Valleján, B., Sánchez, M., Imbert, C., Villar, M. V. \& Van Geet, M. (2011). Hydromechanial behaviour of a heterogeneous compacted soil: experimental observations and modeling. Géotechnique 61, No. 5, 367-386, https://doi.org/10. 1680/geot.SIP11.P.015.

Gracía-Siñeriz, J. L., Mazón, M. R., Kober, F. \& Sakaki, T. (2019). Performance of THM monitoring instrumentation in FEBEX bentonite barrier after 18 years of operation under repositorylike conditions. Geomech. Energy Environ. 17, 75-89.

Guerra, A. M., Cui, Y. J., He, Y., Delage, P., Mokni, N., Tang, A. M., Aimedieu, P., Bornert, M. \& Bernier, F. (2019). Characterization of water retention, compressibility and swelling properties of a pellet/powder bentonite mixture. Engng Geol. 248, 14-21, https://doi.org/10.1016/j.enggeo.2018.11.005.

Jadda, K. \& Bag, R. (2020). Variation of swelling pressure, consolidation characteristics and hydraulic conductivity of two Indian bentonites due to electrolyte concentration. Engng Geol. 272, 105637, https://doi.org/10.1016/j.enggeo.2020.105637.

JIS (Japanese Industrial Standards) (2009). JIS A 1203: Test method for water content of soils. Tokyo, Japan: Japanese Standards Association.

JIS (2019). JIS Z 2451: Test method for methylene blue adsorption on bentonite and acid clay. Tokyo, Japan: Japanese Standards Association.

JNC (Japanese Nuclear Cycle Development Institute) (2000). H12: project to establish the scientific and technical basis for HLW disposal in Japan. Supporting report 2: repository design and engineering technology, Report JNC TN 1400 2000-003. Ibaraki, Japan: Japan Nuclear Cycle Development Institute.

Johansson, E., Äikäs, K., Autio, J., Hagros, A., Malmlund, H., Rautakorpi, J., Sievänen, U., Wanne, T., Anttila, P. \& Raiko, H. (2002). Preliminary KBS-3H layout adaptation for the Olkiluoto site - analysis of rock factors affecting the orientation of a KBS$3 H$ deposition hole, POSIVA Working Report 2002-57. Eurajoki, Finland: Posiva Oy.

Karnland, O., Olsson, S., Nilsson, U. \& Sellin, P. (2007). Experimentally determined swelling pressures and geochemical interactions of compacted Wyoming bentonite with highly alkaline solutions. Phys. Chem. Earth 32, No. 1-7, 275-286.

Komine, H. \& Ogata, N. (2004). Predicting swelling characteristics of bentonites. J. Geotech. Geoenviron. Engng 130, No. 8, 818-829.

Kudo, K., Tanaka, Y., Yokokura, T. \& Kitamura, I. (2005). Investigation of measuring swelling pressure of compacted bentonite. Proceedings of 40th annual meeting of Japan Geotechnical Society, Hokkaido, Japan, pp. 2573-2574 (in Japanese).

Kyokawa, H., Ohno, S. \& Kobayashi, I. (2020). A method for extending a general constitutive model to consider the electro-chemo-mechanical phenomena of mineral crystals in expansive soils. Int. J. Numer. Analyt. Methods Geomech. 44, No. 6, 749-771.

Lee, J. O., Lim, J. G., Kang, I. M. \& Kwon, S. (2012). Swelling pressures of compacted Ca-bentonite. Engng Geol. 129-130, 20-26.

Nakamura, K., Tanaka, Y., Hironaga, M., Tanai, K. \& Kikuchi, H. (2010). Survey on current status of laboratory test method and experimental consideration for material containing bentonite, Report of 2009 collaboration research between JAEA and CRIEPI N981001. Chiba, Japan: Central Research Institute of Electric Power Industry (in Japanese).

Nakayama, M., Ohno, H., Nakayama, M. \& Kobayashi, M. (2016). Collection of measurement data from in situ experiment for performance confirmation of engineered barrier system at Horonobe Underground Research Laboratory (FY2015), Report JAEA-Data/Code 2016-005. Ibaraki, Japan: Japan Atomic Energy Agency (in Japanese).

Namikawa, T. \& Kanno, T. (1997). Consolidation characteristics of buffer materials, Report PNC TN 8410 97-051. Ibaraki, Japan: Power Reactor and Nuclear Fuel Development Corporation (in Japanese).

Namikawa, T., Hirai, T., Tanai, K., Yui, M., Shigeno, Y., Takaji, K. \& Ohnuma, M. (2004). Study on applicability of elasto-viscoplastic models to mechanical properties of compacted bentonite. J. Jap. Soc. Civ. Engng 764, No. III-67, 367-372 (in Japanese).
Namioka, S., Masuda, R., Chijimatsu, M. \& Shimizu, H. (2017). Analysis of the deformation following performance of bentonite/sand mixture. Proceedings of 7 th international conference on clays in natural and engineered barriers for radioactive waste confinement, Davos, Switzerland, pp. 636-638.

Navarro, V., De la Morena, G., Yustres, Á., González-Arteaga, J. \& Asensio, L. (2017). Predicting the swelling pressure of MX-80 bentonite. Appl. Clay Sci. 149, 51-58.

NUMO (2013). Safety of the geological disposal project 2010 - safe geological disposal based on reliable technologies, NUMO technical report NUMO-TR-13-05. Tokyo, Japan: Nuclear Waste Management Organization of Japan (NUMO).

Pusch, R. (1992). Use of bentonite for isolation of radioactive waste products. Clay Miner. 27, No. 3, 353-361.

Roscoe, K. H. \& Burland, J. B. (1968). On the generalized stressstrain behaviour of 'wet' clay. In Engineering plasticity (eds J. Heyman and F. A. Leckie), pp. 565-570. Cambridge, UK: Cambridge University Press.

Sahara, F., Murakami, T., Kobayashi, I., Mihara, M. \& Ohi, T. (2008). Modelling for the long-term mechanical and hydraulic behavior of bentonite- and cement-based materials considering chemical transitions. Phys. Chem. Earth 33, Suppl. 1, S531-S537.

Sasakura, T., Kuroyanagi, M. \& Okamoto, M. (2002). Studies on mechanical behaviour of bentonite for development of the constitutive model, Report JNC TJ8400-2002-025. Ibaraki, Japan: Japan Nuclear Cycle Development Institute (in Japanese).

Sato, H. (2008). Thermodynamic model on swelling of bentonite buffer and backfill materials. Phys. Chem. Earth 33, Suppl. 1, S538-S543.

Sato, H. \& Suzuki, S. (2003). Fundamental study on the effect of an orientation of clay particles on diffusion pathway in compacted bentonite. Appl. Clay Sci. 23, No. 1-4, 51-60.

Sellin, P. \& Olivier, X. L. (2013). The use of clay as an engineered barrier in radioactive-waste management - a review. Clays Clay Miner. 61, No. 6, 477-498, https://doi.org/10.1346/CCMN.2013. 0610601.

Siddiqua, S., Blatz, J. \& Siemens, G. (2011). Evaluation of the impact of pore fluid chemistry on the hydromechanical behaviour of clay-based sealing materials. Can. Geotech. J. 48, No. 1, 199-213.

Sridharan, A., Rao, A. S. \& Sivapullaiah, P. V. (1986). Swelling pressure of clays. Geotech. Test. J. 9, No. 1, 24-33.

Suzuki, H. \& Fujita, T. (1999). Swelling characteristics of buffer material, Report JNC TN8400 99-038. Ibaraki, Japan: Japan Nuclear Cycle Development Institute (in Japanese).

Tanai, K., Kikuchi, H., Nakamura, K., Tanaka, Y. \& Hironaga, M. (2010). Survey on current status of laboratory test method and experimental consideration for material containing bentonite, report of collaboration research between JAEA and CRIEPI JAEAResearch 2010-2025. Ibaraki, Japan: Japan Atomic Energy Agency (JAEA) (in Japanese).

Tanaka, Y. \& Watanabe, Y. (2016). Consolidation on effects of microstructure change on stress-strain relationship of saturated bentonite. J. Japan Soc. Civ. Engng 72, No. 4, 339-353 (in Japanese).

Tanaka, Y. \& Watanabe, Y. (2019). Modelling the effects of test conditions on the measured swelling pressure of compacted bentonite. Soils Found. 59, No. 1, 136-150.

Villar, M. V. \& Lloret, A. (2008). Influence of dry density and water content on the swelling of a compacted bentonite. Appl. Clay Sci. 39, No. 1-2, 38-49, https://doi.org/10.1016/j.clay.2007.04.007.

Wang, Q., Tang, A. M., Cui, Y. J., Delage, P. \& Gatmiri, B. (2012). Experimental study on the swelling behaviour of bentonite/clay stone mixture. Engng Geol. 124, 59-66.

Watanabe, Y. \& Yokoyama, S. (2020). Montmorillonite content of bentonites considering accuracy of methylene blue adsorption test. J. Japan Soc. Civ. Engng 76, No. 1, $26-39$ (in Japanese).

Zeng, Z., Cui, Y. J., Zhang, F., Conil, N. \& Talandier, J. (2019). Investigation of swelling pressure of bentonite/claystone mixture in the full range of bentonite fraction. Appl. Clay Sci. 178, 105137, https://doi.org/10.1016/j.clay.2019.105137.

Zeng, Z., Cui, Y. J., Conil, N. \& Talandier, J. (2020). Effects of technological voids and hydration time on the hydro-mechanical behaviour of compacted bentonite/claystone mixture. Géotechnique, https://doi.org/10.1680/jgeot.19.P.220. 
Zhang, F., Ye, W. M., Chen, Y. G., Chen, B. \& Cui, Y. J. (2016). Influence of salt solution concentration and vertical stress during saturation on the volume change behavior of compacted GMZ01 bentonite. Engng Geol. 207, 48-55, https://doi.org/10. 1016/j.enggeo.2016.04.010.

Zhang, F., Ye, W. M., Wang, Q., Chen, Y. G. \& Chen, B. (2019). An insight into the swelling pressure of GMZ01 bentonite with consolidation of salt solution effects. Engng Geol. 251, 190-196, https://doi.org/10.1016/j.enggeo.2019.02.016.

Zhao, J., Chen, L., Collin, F., Liu, Y. \& Wang, J. (2016) Numerical modeling of coupled thermal-hydro-mechanical behavior of GMZ bentonite in the China-Mock-up test. Engng Geol. 214, 116-126, https://doi.org/10.1016/j.enggeo. 2016.09.015. 